DOI https://doi.org/10.30525/978-9934-571-83-1-16

\title{
ESTABLISHMENT OF PROSECUTION SERVICE OF UKRAINE AS INSTITUTE OF HUMAN RIGHTS AND FREEDOMS, PUBLIC AND STATE INTERESTS PROTECTION
}

\author{
Naulik N. S.
}

\section{INTRODUCTION}

The Constitution of Ukraine, at the level of modern international standards, has provided for the rights, freedoms, and obligations of a person and a citizen in Ukraine. The constitutional rights and freedoms are guaranteed by the state opportunities that allow each person and citizen to freely and independently choose the patterns of their behavior, to use the given social benefits in the personal and public interests. The rights and freedoms enshrined in the Fundamental Law of Ukraine constitute a coherent system that ensures the constitutional and legal status of a person. The basis of the legal status of a person is personal rights and freedoms; political rights and freedoms; economic, social, and cultural rights.

In this regard, any democratic state must ensure the conditions for strengthening the observance of human rights and improving procedures for violated rights protection, as well as for simplification of such procedures. The implementation of these principles and maintenance of real protection are to be reinforced by the system of relevant state authorities.

Ukraine has built up a well-defined system of authorities and officials at different levels, who are empowered to protect the rights and freedoms of a person and a citizen, i.e. the President of Ukraine, the Verkhovna Rada of Ukraine, the Cabinet of Ministers of Ukraine, local state administrations, courts of general jurisdiction and specialized courts, the Constitutional Court of Ukraine, the Ukrainian Parliament Commissioner for Human Rights, the prosecution service, the legal service, and other law enforcement agencies of Ukraine.

In modern democratic societies, the prosecution service performs an extremely important law enforcement and rights protection role. The nature of its operation is specified by its place among other state authorities, as well as by its functions, activities, and powers granted by the law. However, the reform of the prosecution service of Ukraine aimed at meeting the requirements of the European Union forces to reconsider the role and place of this authority among other state institutions, as well as in the system of human rights and freedoms 
protection, and introduces a new concept of protecting public and state interests by public prosecutors.

The above-mentioned situation makes the study of the role of the prosecution service as of a multifunctional state authority aimed at protecting human rights a promising area of research.

\section{Historical review of the prosecution service establishment in Ukraine}

The democracy of any state is determined by its attitude to human rights and freedoms, public and state interests. Therefore, to develop and strengthen a democratic state is impossible without strengthening the public consciousness and social practice of inalienable rights and freedoms, enshrining their guarantees in legislation, working out the mechanism of human rights protection and their violation prevention.

One of the elements of such a mechanism is the institute of the prosecution service of Ukraine, the establishment of which took place under the influence of social, economic, and political factors. Scientists have suggested that the history of the prosecution service consists of more than seven centuries. This state institute arose from the needs and interests of the royal authorities (as it is known, the homeland of the prosecution service is France) and was originally formed as an independent institution. On the territory of Ukraine, which was part of the Russian Empire, and then the Union of Soviet Socialistic Republics, the prosecution service has been existing for more than 270 years ${ }^{1}$.

Ukrainian scholars have different approaches to the study of the genesis of the prosecution service in Ukraine. O. Lytvak, P. Shumskyi, O. Mykhailenko, A. Matviiets, and others present historical and legal analysis as one array, from ancient times to the present ${ }^{2}$.

M. Siryi has quite an interesting approach to defining the stages of the historical development of the prosecution service. He highlights three historical and legal traditions: the tradition of the Russian imperial prosecutor's office as an administrative and supervisory body (the prosecutor's office - "the eye of the sovereign"); the Ukrainian historical and legal tradition of the formation of the prosecution serviced from the X to the XVIII century and at the time of the Ukrainian National Republic (based on close ties with the legal service and the

\footnotetext{
1 Литвак О., Шумський П. Становлення та розвиток прокуратури України. Вісник націіональної академї прокуратури України. 2012. № 3. С. 10-15 (С. 10).

2 Литвак О., Шумський П. Становлення та розвиток прокуратури України. Вісник національної академї прокуратури Украӥни. 2012. № 3. С. 10-15 (С. 10); Михайленко О.Р. Прокуратура України : підручник / O.P. Михайленко. 2-ге вид., перероб. та допов. Київ : Хрінком Інтер, 2011. 336 с. (C. 35-45); Прокурорський нагляд за додержанням i застосуванням законів : навчальний посібник. / І.С. Зарубинська, О.М. Толочко, А.А. Матвієць, Н.С. Наулік та ін. Київ : Алерта, 2013. - 550 с. (С. 9-11).
} 
court); the historical and legal tradition of the prosecutor's office of the Soviet Era with the inherited ideas of the Russian Empire ${ }^{3}$.

It is worth agreeing with V. Kravchuk, who points the impoverishment of scientific research by authors who leave out the attention of the period of development of the prosecutor's office during the revival of the Ukrainian State (1917-1921) ${ }^{4}$. The author proposes his periodization of Ukrainian prosecution service development and highlights the following five periods:

1) the emergence and development of the functions of the prosecutor's office in the times of the Cossack State - the period of the Ukrainian Cossack State;

2) prosecutor's office on Ukrainian lands during the Russian Empire - the period of Ukraine being under the rule of the Russian Empire;

3) prosecutor's office in the times of the Ukrainian National Republic - the period of the Ukrainian National Revival at the beginning of the XX century;

4) the Soviet prosecutor's office - the Soviet period;

5) the prosecutor's office of the modern Ukrainian state - the period of the establishment and development of sovereign and independent Ukraine ${ }^{5}$.

However, this approach, in our opinion, is incomplete, since, according to V. Maliuha, the prosecutor's office has its origin from antiquity ${ }^{6}$.

Thus, analyzing the research outcomes of the mentioned scientists, the history of establishment and development of the Ukrainian prosecution service can be divided into the following eight periods:

1) prosecutor's office in antiquity;

2) prosecutor's office in the Cossack State;

3) prosecutor's office on Ukrainian lands in the Russian Empire;

4) prosecutor's office in Galicia;

5) prosecutor's office during the period of Ukrainian National Revival;

6) prosecutor's office of the Ukrainian Soviet Socialistic Republic;

7) prosecutor's office of the post-Soviet period;

8) prosecutor's office in modern Ukraine.

Each period of the Ukrainian prosecution service development manifests itself in a special complex of responsibilities and powers of prosecutors, in procedures of formation of the prosecutor's offices, in the existence of the structured organization or just individual prosecutors. These unique features of the

\footnotetext{
3 Сірий М. Не «око государеве», а захисник публічного інтересу. Сучасні перспективи реформи прокуратури. Дзеркало тижня. 2009. № 18 (746). 22-29 травня 2009.

4 Кравчук В.М. Інституційно-правовий аспект функціонування прокуратури України як органу державної влади : монографія. Тернопіль : ТзОВ «Тернограф», 2013. 272 с. (С. 90)

5 Див. там само. С. 92.

6 Малюга В.І. Принципи організації та діяльності прокуратури України : дис. ... канд. юрид. наук: спец. 12.00.10 «Судоустрій; прокуратура та адвокатура». Київ, 2002. 205 с.(С. 182).
} 
prosecution office indicated its place and role in the system of human rights and freedoms, public and state interests' protection.

The prosecutor's office in the Cossack State is characterized by the emergence of an institute of "instigatorism". The priority task of instigators (prosecutors) was to ensure the rule of law, and the main function - to monitor compliance with laws in various spheres, mainly in judicial institutions ${ }^{7}$.

In the Polish language, the word instigator means an official who was charged with prosecutorial duties to supervise the administration of justice and to prosecute the violators of public order. Besides two main instigators, one Instigator for the Crown and one for Grand Duchy of Lithuania, there were special instigators in courts. Sometimes they were called the royal prosecutors. Somewhat later, in the so-called Duchy of Ruthenia, the positions of an instigator and vice-instigator were introduced to participate in the administration of justice and to perform other monitor functions ${ }^{8}$.

There were special requirements for persons who wanted to become an instigator. Instigators were elected from among judges, as the representatives of this profession were considered to have the relevant knowledge and skills. Information about the election of candidates for these positions was then transferred to the municipal starosta, who appointed judges, burgomasters, vogts, and instigators 9 .

By the middle of the XV century, professional prosecutors and lawyers began to appear in courts. These legal professionals received education at universities in Western Europe, as well as at the Jagiellonian University (founded in 1364), among students of which there were a lot of Ukrainians ${ }^{10}$.

Subsequently, the array of instigator's competencies became wider, and they began to manage certain financial issues, i.e. royal taxes and other fees (mainly from trade). Moreover, they had powers to file claims against those who failed to pay taxes and fees or tried to hide their incomes.

In Ukraine, the position of a prosecutor (instigator) continued to exist in the XVII-XVIII. Thus, as mentioned in the book of V. Sverbyhuza, Ukrainian Tribunal consisted of Hetman, General Scriber, General Judges, Prosecutor, and other officials ${ }^{11}$.

It follows that the legislation and practice of those times did not distinguish between principles, the basis of organization and operation of the prosecutor's

\footnotetext{
7 Грицаєнко Л.Р. Історико-правові витоки інституту прокуратури в Україні. Вісник прокуратури. 2008. № 2 (80). С. 94-104. (С. 103).

8 Грицаєнко Л. Історико-правовий процес утвердження інституту прокуратури в Україні. Право Украӥни. 2008. № 11. С. 123.

${ }^{9}$ Див там само. С. 121-129.

10 Див там само. С. 125.

11 Див там само С. 128.
} 
office. The conclusions concerning the framework for the prosecution service organization can be made only on the basis of analysis of historical facts of the prosecution service genesis and development, the practice of prosecution and bringing offenders to justice.

At those times, the prosecution service was included in the system of state authorities. Its monitoring activity can be associated with the rights protection one, however, it was directed on the protection of imperial monarchical interests. It was then that the basic forms, methods, principles of organization and activity of the prosecution service were formed, which later became an integral part of the modern prosecution service of Ukraine ${ }^{12}$.

Another important stage in the history of establishment and development of the prosecution service of Ukraine was the creation of the prosecutor's office in Galicia under Austria and Austria-Hungary from 1849 until 1918. The prosecutor's office in Galicia was found under the influence of the European legal system.

The positions of state prosecutors first appeared in the 1840s. Then, in 1855, the unified system of state prosecutor's offices was established, which consisted of higher state prosecutor's offices and subordinate state prosecutor's offices. In 1851 Galicia financial prosecutor's office in Lviv was found, which had its subordinate departments.

During the period of Ukrainian National Revival, the law on prosecution service of independent Ukrainian State was adopted. The Law "On Establishment of the General Court" specified the structure of the Court, which consisted of civil, criminal, and administrative departments and a prosecutor's office.

The stage of the prosecution service development went through the Soviet period. The prosecutor's office of the Ukrainian Soviet Socialistic Republic was found as an integral part of the People's Commissariat of Justice and was subordinate to the People's Commissar of Justice.

The main functions of the prosecutor's office of the Ukrainian Soviet Socialistic Republic were the following:

- to supervise, on behalf of the state, the legality of all actions of all authorities, economic institutions, public and private organizations and individuals through the criminal prosecution of offenders and the appeal against the resolutions violating the law;

- to supervise the operation of law-enforcement authorities during the investigation;

\footnotetext{
12 Шестопалов Р.М. Історичні передумови становлення та розвитку правозахисної діяльності органів прокуратури України. Науковий вісник Дніпропетровського державного університету внутрішніх справ. 2012. № 2. C. 145.
} 
- to support the public prosecution in court;

- to participate in civil proceedings;

- to supervise the proper detention of prisoners in custody ${ }^{13}$.

The Constitution of the Ukrainian Soviet Socialistic Republic of 1937 stated that the Prosecutor of the Union of Soviet Socialist Republics had the power to appoint the Prosecutor of the Ukrainian Soviet Socialistic Republic. According to the Arts. 112, 113 of the Constitution of the Ukrainian Soviet Socialistic Republic of 1937 the highest supervision over the exact implementation of the laws by all people's commissars and subordinate to them institutions, as well as separate officials, as well as citizens on the territory of the Ukrainian Soviet Socialistic Republic (the Ukrainian SSR) was carried out by the Prosecutor of the Union of Soviet Socialist Republics (the USSR) directly, as well as through the Prosecutor of the Ukrainian SSR. The Prosecutor of the Ukrainian SSR was appointed by the Prosecutor of the USSR for the period of 5 years ${ }^{14}$.

On 11 September 1929 the Regulations "On the Judicial System of the Ukrainian SSR" were adopted. These Regulations provided for transferring the investigation department to the prosecution service aimed at managing, administering and supervising its procedural activities ${ }^{15}$.

On 20 June 1933, the Prosecutor's Office of the USSR was created and was entrusted with the next functions: to supervise the correct application of laws by the courts and to perform the general management of prosecutor's offices in other republics. On 17 December 1933, the Regulations "On Prosecutorial Supervision of the USSR" was approved. Art. 1 of these Regulations stated: "The main task of the USSR Public Prosecutor's Office is to strengthen socialist rule of law and protect public property from the attack of anti-social elements throughout the USSR" ${ }^{\prime 16}$. The prosecution service became virtually a punitive machine in the hands of the ruling nomenclature. Some secret instructions emphasized the particular struggle against violators of revolutionary law, in particular those who committed crimes against the state and abducted socialist property. Despite the fact that the prosecutor's office was primarily a supervisory authority, it nevertheless performed a punitive function, which corresponded de facto to criminal orders of the authorities.

In the second half of the 1930s, the prosecution service underwent changes. In 1936, a new Constitution was adopted in the former USSR. For the first time,

\footnotetext{
${ }^{13}$ Мурза В.В. Структура та організація роботи органів прокуратури УСРР ( 20-ті - початок 30-х рр.. ХХ ст.). Вісник національного університету внутрішніх справ. Вип. 15. 2001. С. 156-162. (С. 158-159).

14 Конституція Української Радянської Соціалістичної Республіки : від 20 квіт. 1978 року. URL: http://zakon5.rada.gov.ua/laws/show/888-09.

${ }_{15}$ Сухонос В.В. Прокурорський нагляд за додержанням законів органами дізнання: історичний аспект. Прокуратура. Людина. Держава. 2004. № 9. С. 18-19.

${ }^{16}$ Сухонос В.В. Прокуратура в системі державних органів України: теоретичний аналіз сучасного стану та перспектив розвитку : монографія. Суми : ВТД «Університетська книга», 2008. С. 74-75.
} 
prosecutorial supervision was proclaimed as an independent form of state activity and the whole Section IX of the Constitution "Court and Prosecutor's Office" was devoted to that issue.

Since the beginning of the Great Patriotic War, the prosecutor's office, as well as other state bodies, switched to an intensified regime associated with the introduction of martial law. A special accent was made on the struggle against any rear disorganizers, deserters, alarmists, gossips, and all those who impeded the realization of defense ${ }^{17}$. It is clear that at those times priority was given to the principles of strict implementation of laws and compliance with orders of military leadership.

In 1953, the prosecution service began to work more actively on rehabilitation of illegally repressed people. Already June Plenum of the Central Committee of the Communist Party of the Soviet Union in 1953 proclaimed a course on the restoration of internal party democracy, the abolition of abuses ${ }^{18}$. However, despite the declarative democratization of the provisions governing the activities of the prosecutor's offices, which was definitely a positive manifestation, the prosecutor's offices remained, in fact, the tools for implementing the policy of the ruling nomenclature.

The Constitution of the USSR of 1977 and 1978 contained provisions on the organization and activities of the prosecutor's office. In particular, it was established that "the highest supervision over the exact and uniform implementation of laws by all ministries, state committees and departments, enterprises, institutions and organizations, executive and regulatory bodies of local councils of people's deputies, collective farms, cooperative and other public organizations, officials, as well as citizens on the territory of Ukraine is carried out by the Prosecutor General of the USSR and his subordinate Prosecutor of the Ukrainian SSR and other subordinate prosecutors"19.

Since the proclamation of independence, the prosecutor's office of Ukraine has become independent of federal authorities, and, in fact, it has become an independent structure that needed changes and reforms. That was why, on 5 November 1991, the Law of Ukraine "On the Prosecutor's Office" was adopted. Its hasty adoption reveals the importance of the prosecution service for the new government ${ }^{20}$.

Art. 6 of the Law of Ukraine "On the Prosecutor's Office" adopted on 5 November 1991 defined one of the main principles of the prosecution service activity - protection of human rights and freedoms on the basis of equality

\footnotetext{
17 Див там само. С. 82.

18 Див там само. С. 89.

19 Див. там само.

20 Про прокуратуру : Закон від 05.11.1991 № 1789-XII. Верховна Рада України. URL: http://zakon2.rada.gov.ua/laws/show/1789-12/ed19911105/conv.
} 
before justice, with no privileges or restrictions based on race, skin colour, political, religious, and other beliefs, gender, ethnic and social origin, property status, place of residence, linguistic or other characteristics, and implementation of measures aimed at restoring violated rights and bringing the persons responsible for such violations to justice ${ }^{21}$.

Arts. 121-123 of the Constitution of Ukraine of 1996 defined the prosecutor's office as a single system, its functions, the procedure for the appointment and dismissal of the Prosecutor General of Ukraine, and the term of office ${ }^{22}$.

After Ukraine joined the Council of Europe and defined the pro-European course of development, the task to reform the prosecutor's office of Ukraine arose. The commitments taken by Ukraine in the Council of Europe on reforming the prosecutor's office led to the need for further improvement of the legislation and the adoption by the Verkhovna Rada of Ukraine on 14 October 2014 of the new Law of Ukraine "On Prosecutor's Office", which defined the role and place of supervision over observance and application of laws in the prosecutor's activities. Such supervision is carried out under the new Law exclusively in the form of representing the rights and freedoms of a citizen, the interests of society and the state ${ }^{23}$.

The analysis of the latest constitutional changes of the status of the prosecutor's office, in particular, its functional component, shows that the prosecutor's office is referred to the section of justice, and Art. 131-1 of the Constitution of Ukraine states that the prosecutor's office operates in Ukraine: 1) to maintain a public prosecution in court; 2) to organize and to perform the procedural guidance of the pre-trial investigation, to resolve other issues during criminal proceedings in accordance with the law, to supervise secret and other investigative actions of law enforcement agencies; 3 ) to represent the interests of the state in court in exceptional cases and in the manner prescribed by law ${ }^{24}$.

\section{Establishment and development of the prosecution service of Ukraine in the structure of the mechanism of the state}

The reform of criminal justice in Ukraine prompted the legislator to define a new vector for the development of the prosecutor's office in Ukraine. According to the requirements of the European community, this Law defines the legal status of the new prosecutor's office of Ukraine, and therefore it is no accident

\footnotetext{
${ }^{21}$ Організація роботи та управління в органах прокуратури : навчальний посібник у запитаннях $\mathrm{i}$ відповідях // За загальною редакцією Якимчука М.К. та Європіної І.В. Київ: Національна академія прокуратури України. 2009. 207 с. С.13.

${ }^{22}$ Конституція України : від 28 черв. 1996 р. Відомості ВРУ. 1996. № 30. Ст. 141.

${ }^{23}$ Про прокуратуру : Закон України від 14 жовтня 2014 року. Відомості Верховної Ради (BВP), 2015, № 2-3, ст.12.

${ }^{24}$ Про внесення змін до Конституції України (щодо правосуддя) : Закон України № 1401-VIII від 2 червня 2016 року. Голос Украӥни. № 118, 29 червня 2016 року.
} 
that Art. 1 of the Law of Ukraine "On Prosecutor's Office" of 14 October 2014 defines the notion of the prosecutor's office of Ukraine: "The Public Prosecution Service of Ukraine constitutes a unified system that shall, in line with the procedures set hereby, perform functions established by the Constitution of Ukraine with the aim of protecting human rights and freedoms, common interests of the society and the state" 25 .

The term prosecutor's office (from the Latin "procurare" - to take care, to provide, to administer) is the state body supervising the implementation of laws, prosecuting and maintaining the prosecution in court ${ }^{26}$.

In accordance with Art. 121 of the Constitution of Ukraine ${ }^{27}$ and the Law of Ukraine "On Prosecutor's Office" of 14 October 2014, the prosecutor's office is a unified system. Unity means close ties, cohesiveness, integrity, indivisibility; the combination to make a single whole, the continuity of connection.

The functional content of the prosecutor's office is a controversial issue that attracts the attention of the European community. In particular, the Consultative Council of European Prosecutors (CCEP) in its Opinions specifies that in most legal systems, prosecutors have powers, sometimes significant, in civil, commercial, social and administrative matters, even the power to monitor the legitimacy of government decisions ${ }^{28}$.

In accordance with Recommendation Rec (2012) 11 "The Role of Prosecutors outside the Criminal Justice System", the prosecutor's office exercises its responsibilities and powers with particular attention to the protection of human rights and fundamental freedoms and in full compliance with the rule of law; the mission of the prosecutor's office outside the criminal justice system is to represent the general or public interest, protect human rights and fundamental freedoms, and uphold the rule of law ${ }^{29}$.

With the adoption of the Law of Ukraine "On Prosecutor's Office" (the Law), the legislator in paragraph 1 of Section XIII of the Transitional Provisions defines that the prosecutor's office oversees the compliance with human rights and freedoms and the corresponding laws by the executive authorities, local selfgovernment and their officials exclusively by representing the interests of a citizen in the $\operatorname{court}^{30}$.

\footnotetext{
25 Закон України «Про прокуратуру»: від 14 жовтня 2014 року. Відомості ВРУ, 2015, № 2-3, Ст. 12.

${ }^{26}$ Великий енциклопедичний юридичний словник / За ред. Акад. НАН України Ю.С. Шемшученка. 2ге вид., переробл. І доповн. Київ : Вид-во «Юридична думка», 2012. 1020 с. (С. 755).

${ }^{27}$ Конституція України: від 28 червня 1996 р. Відомості ВРУ. 1996. № 30. Ст. 141.

${ }^{28}$ Статус органів публічного обвинувачення: міжнародні стандарти, зарубіжне законодавство і пропозиції щодо реформування в Україні / за заг. редакцією О.А. Банчука. Київ : Атіка, 2012. 624 с. (С. 323).

${ }^{29}$ Recommendation CM / Rec (2012) 11 of the Committee of Ministers to member States on the role of public prosecutors outside the criminal justice system URL: https://www.coe.int/.

30 Закон України «Про прокуратуру»: від 14 жовтня 2014 року. Відомості ВРУ, 2015, № 2-3, Ст. 12.
} 
The prosecutors exercise their responsibilities and powers to protect human rights and freedoms, general interests of society and state.

The protection of human rights and freedoms is a constitutional and international obligation of the modern state, which is implemented through a system of principles, institutions, mechanisms, procedural and legal rules. The state must protect the interests of the individual guarantee public interests. In most democratic states, the main mechanism for the protection of human rights is the court (the USA, Canada), the constitutional complaint (Germany, Austria, Spain), the ombudsman (Sweden, Norway, Finland), etc. ${ }^{31}$.

Human rights protection activities are the following: to provide legal aid to every citizen, as well as legal entities, foreigners, and stateless persons in controversial issues of law enforcement, abuse of law; to protect individuals from prosecution; to guarantee the protection of human rights by human rights protection authorities ${ }^{32}$.

Human rights refer to the capabilities to behave in a certain manner to ensure the individual's well-being, development, and satisfaction of his/her needs. Human rights manifest themselves in two aspects: natural human rights, inseparably linked with an individual's existence and development; acquired human rights, which characterize an individual's social and political status.

The Constitution of Ukraine, at the level of modern international standards, has consolidated the rights, freedoms, and responsibilities of a person and a citizen in Ukraine. Constitutional rights and freedoms are guaranteed by state opportunities, which allow each person and citizen to freely and independently choose the form and extent of his/her behavior, to use the social benefits provided to him/her in the personal and general interests. The basis of the legal status of a person is personal rights and freedoms. They are the following rights: to life; to respect for dignity; to freedom and personal inviolability; to the inviolability of domicile; to privacy of correspondence, telephone conversations, telegraph, and other communications; to non-interference in private life and family matters; to free choice of place of residence; to the freedom of thought and speech; to freedom of beliefs and religion (Arts. 27-35 of the Constitution of Ukraine). The Constitution of Ukraine enshrines political rights and freedoms, that is, the rights that belong to a person as a member of the political community when he/she acts as a citizen of the state. They relate to participation in public life and in the management of the state. The Constitution of Ukraine specifies economic, social and cultural rights. These rights are connected with human activity in the economic sphere, individual's social relations with society,

\footnotetext{
31 Наулік Н.С. Інститут омбудсмена в Україні та Республіці Польща: порівняльне дослідження : монографія. Тернопіль : Воля, 2009. 178 с. (С. 58).

32 Суд, правоохоронні та правозахисні органи України : підручник / О.С. Захарова, В.Я. Карабань, В.С. Ковальський (кер. авт. кол.) та ін.; Відпов. ред. В. Маляренко. Київ : Юрінком Інтер, 2004. 376 с. (С. 23 ).
} 
the state, communities, other people, and with activity in the field of cultural and spiritual life.

In this regard, any democratic state must ensure the conditions for strengthening the observance of human rights and improving procedures for violated rights protection, as well as for simplification of such procedures. The implementation of these principles and maintenance of real protection are to be reinforced by the system of relevant state authorities, including the prosecutor's office among others.

The international community pays great attention to human rights, thus, it establishes through various agreements international legal standards, that is legal norms of acceptable relations between an individual and a state.

Human rights derive from the natural rights inherent in human since birth and apply to all people living in a particular state (citizens of the state, citizens of other states, stateless persons). The rights of a citizen are fixed by the person due to his/her belonging to the citizenship of the state (citizens have political and other rights, which do not have other persons).

Accordingly, the prosecutor's office carries out constitutional functions in order to protect human and civil rights and freedoms. Also, the implementation of the prosecutor's office functions aims at protecting the general interests of society and the state.

Interests are the objective relations between human needs and the environment, where these needs are satisfied in the course of a particular activity. Public interests are viewed as the motivating forces of the social groups' activity, which underlie the relevant managerial influences on this activity.

The starting point for analyzing social interests is the category of social needs. Needs as a way of realizing social relations are the immanent essence of the individual; interests are an "external" form of social relations. The content of interests is formed on the basis of both the needs and the social means involved in the implementation of the latter.

An individual satisfies needs only in society, interests are realized when conflicts, caused by the needs of different social classes and groups, are solved. Interests are objective, so one of the essential issues is their awareness. The success of the realization of the interests of different social classes and groups is directly related to the degree of their awareness: if objective interests are not understood or poorly understood, a social group can either achieve a goal that objectively does not meet its interests or do not seek a profitable decision at all.

In accordance with the Decision of the Constitutional Court of Ukraine of 8 April 1999, о. 3-рп/99, state interests are established in accordance with the norms of the Constitution of Ukraine and the norms of other legal acts. Interests 
of the state differ from the interests of other participants in public relations. The state interest is always a need for the implementation of national (political, economic, social and other) actions, programs aimed at protecting sovereignty, territorial integrity, state border of Ukraine, guaranteeing its state, economic, informational, ecological safety, protection of land as national wealth, protection of the rights of all subjects of property rights and management, etc. ${ }^{33}$.

Thus, the interests of the state are enshrined in the norms of the Constitution of Ukraine and other legal acts requirements for the implementation of national (political, economic, social and other) actions, programs aimed at protecting sovereignty, territorial integrity, the state border of Ukraine, guaranteeing its state, economic, information, ecological safety, protection of land as a national wealth, protection of the rights of all subjects of property rights and management, etc. Analyzing the aforementioned concepts, it can be argued that the general interests of society and the state should be understood as "legitimate interests".

\section{CONCLUSIONS}

Thus, it should be noted that in all determined periods of the genesis and development of the prosecution service of Ukraine, its place and role in the system of protection of human rights and freedoms, the interests of society and the state was determined by the stage of development of the state, the existence of the state as such, the form of government and the existing state regime of Ukraine.

With the reform of the prosecutor's office of Ukraine, it is obvious that its system is changing, as well as the criteria on which such a system is being built. To date, the modern legislation specifies the independence of prosecutors in exercising their responsibilities and powers, moreover, it has changed the requirements for subordination of prosecutor's offices of different levels. The system of the prosecution service of Ukraine is independent of administrative division of the state. This means that local prosecutor's offices are created without any connection to separate administrative units.

Acting as a representative of the interests of citizens or state in court, the prosecutor implements exclusively constitutional provisions, which are enshrined in the Constitution of Ukraine, according to which the state undertakes the obligation to protect the rights and freedoms of citizens, as well as all subjects of property and economic rights. The prosecutor has a special status and authority established by law and acts as a representative of the state

33 Рішення Конституційного Суду України у справі за конституційними поданнями Вищого арбітражного суду України та Генеральної прокуратури України щодо офіційного тлумачення положень статті 2 Арбітражного процесуального кодексу України (справа про представництво прокуратурою України інтересів держави в арбітражному суді) від 8 квітня 1999 року № 3-pп/99: URL: http://zakon2.rada.gov.ua/laws/show/v003p710-99. 
authority, which enables him/her to act as the guarantor of legality in the implementation of legal proceedings.

The reform of the prosecutor's office of Ukraine at the present stage, regardless of the place in the system of public authorities or branches of power, should be in accordance with the legal system of Ukraine, modern requirements and challenges that arise in the formation of a legal and democratic state. The main criterion for the work of the prosecutor's office should be the protection of the rights and freedoms of humans and citizens, the interests of society and the state. Therefore, changes to the current law must fill all the gaps concerning the prosecutor's office, its functions and tasks, the status of prosecutor and his/her powers.

\section{SUMMARY}

In modern democratic societies, the prosecution service performs an extremely important law enforcement and rights protection role. The nature of its operation is specified by its place among other state authorities, as well as by its functions, activities, and powers granted by the law. However, the reform of the prosecution service of Ukraine aimed at meeting the requirements of the European Union forces to reconsider the role and place of this authority among other state institutions, as well as in the system of human rights and freedoms protection, and introduces a new concept of protecting public and state interests by public prosecutors.

In all determined periods of the genesis and development of the prosecution service of Ukraine, its place and role in the system of protection of human rights and freedoms, the interests of society and the state was determined by the stage of development of the state, the existence of the state as such, the form of government and the existing state regime of Ukraine.

With the reform of the prosecutor's office of Ukraine, it is obvious that its system is changing, as well as the criteria on which such a system is being built. To date, the modern legislation specifies the independence of prosecutors in exercising their responsibilities and powers, moreover, it has changed the requirements for subordination of prosecutor's offices of different levels. The system of the prosecution service of Ukraine is independent of administrative division of the state. This means that local prosecutor's offices are created without any connection to separate administrative units.

The reform of the prosecutor's office of Ukraine at the present stage, regardless of the place in the system of public authorities or branches of power, should be in accordance with the legal system of Ukraine, modern requirements and challenges that arise in the formation of a legal and democratic state. The main criterion for the work of the prosecutor's office should be the protection of the rights and freedoms of humans and citizens, the interests of society and the state. Therefore, changes to the current law must fill all the gaps concerning the prosecutor's office, its functions and tasks, the status of prosecutor and his/her powers. 


\section{REFERENCES}

1. Конституція України : від 28 черв. 1996 р. Відомості ВРУ. 1996. № 30. Ст. 141 .

2. Про внесення змін до Конституції України (щодо правосуддя) : Закон України № 1401-VIII від 2 червня 2016 року. Голос України. № 118, 29 червня 2016 року.

3. Конституція Української Радянської Соціалістичної Республіки : від 20 квіт. 1978 року.URL: http://zakon5.rada.gov.ua/laws/show/888-09.

4. Про прокуратуру : Закон від 05.11.1991 № 1789-XII. Верховна Рада України. URL: http://zakon2.rada.gov.ua/laws/show/1789-12/ed19911105/ conv.

5. Про прокуратуру : Закон України від 14 жовтня 2014 року. Відомості Верховної Ради (ВВР), 2015, № 2-3, ст. 12.

6. Рішення Конституційного Суду України у справі за конституційними поданнями Вищого арбітражного суду України та Генеральної прокуратури України щодо офіційного тлумачення положень статті 2 Арбітражного процесуального кодексу України (справа про представництво прокуратурою України інтересів держави в арбітражному суді) від 8 квітня 1999 року № 3-pп/99. URL: http://zakon2.rada.gov.ua/laws/ show/v003p710-99.

7. Басков В.И. Курс прокурорского надзора. Москва : Изд-во «Зеркало». 1998. С. 15

8. Бережний С.Д. Судова система на Поділлі в XVI - першій половині XIX cт. URL: file:///C:/Users/\%D0\%B2\%D0\%BE\%D0\%BB\%D0\% BE\%D0\%B4\%D1\%8F/Downloads/Unzap_2013_3_7.pdf.

9. Великий енциклопедичний юридичний словник / За ред. Акад. НАН України Ю.С. Шемшученка. 2-ге вид., переробл. і доповн. Київ : Вид-во «Юридична думка», 2012. 1020 с. (С. 755).

10. Грицаєнко Л.Р. Історико-правові витоки інституту прокуратури в Україні. Вісник прокуратури. 2008. № 2 (80). С. 94-104. (С. 103).

11. Грицаєнко Л. Історико-правовий процес утвердження інституту прокуратури в Україні. Право Украӥни. 2008. № 11. С. 121-122.

12. Кравчук В.М. Інституційно-правовий аспект функціонування прокуратури України як органу державної влади : монографія. Тернопіль : ТзОВ «Тернограф», 2013. 272 с. (С. 90).

13. Литвак О., Шумський П. Становлення та розвиток прокуратури України. Вісник національної академії прокуратури Украӥни. 2012. № 3. C. $10-15$ (C. 10). 
14. Малюга B.I. Принципи організації та діяльності прокуратури України : дис. ... канд. юрид. наук : спец. 12.00.10 «Судоустрій; прокуратура та адвокатура». Київ, 2002. 205 с. (С. 182).

15. Михайленко О.Р. Прокуратура України : підручник. 2-ге вид., перероб. та допов. Київ : Хрінком Інтер, 2011. 336 с. (С. 35-45).

16. Мычко Н.И. Прокуратура Украины: роль и место в системе государственной власти. Донецк : Донеччина, 1999. 256 с. (С. 14).

17. Михайленко О.Р. Прокуратура України : підручник. Київ, 2005; Прокуратура України : підручник. / За заг. ред. В.В. Сухоноса. Суми, 2005. C. 35 .

18. Мурза В.В. Структура та організація роботи органів прокуратури УСРР (20-ті - початок 30-х рp. ХХ ст.). Вісник національного університету внутрішніх справ. Вип. 15. 2001. С. 156-162. (С. 158-159).

19. Наулік Н.С. Інститут омбудсмена в Україні та Республіці Польща: порівняльне дослідження : монографія. Тернопіль : Воля, 2009. 178 с. (C. 58).

20. Новицкая Т. Великие реформы Александра II (от ликвидации тайной полиции к введению суда присяжных). Российская юстииия. 1998. № 4. C. 61.

21. Організація роботи та управління в органах прокуратури : навчальний посібник у запитаннях і відповідях / За загальною редакцією Якимчука М.К., та Європіної І.В. Київ : Національна академія прокуратури України. 2009. 207 с. С. 13.

22. Прокурорський нагляд за додержанням і застосуванням законів : навчальний посібник. / І.С. Зарубинська, О.М. Толочко, А.А. Матвієць, Н.С. Наулік та ін. Київ : Алерта, 2013. 550 с. (С. 9-11).

23. Сірий М. Не «око государеве», а захисник публічного інтересу. Сучасні перспективи реформи прокуратури. Дзеркало тижня. 2009. № 18 (746). 22-29 травня 2009.

24. Статус органів публічного обвинувачення: міжнародні стандарти, зарубіжне законодавство і пропозиції щодо реформування в Україні / за заг. редакцією О.А. Банчука. Київ : Атіка, 2012. 624 с. (С. 323).

25. Суд, правоохоронні та правозахисні органи України : підручник / О.С. Захарова, В.Я. Карабань, В.С. Ковальський (кер. авт. кол.) та ін.; Відпов. ред. В. Маляренко. Київ : Юрінком Інтер, 2004. 376 с. (С. 23).

26. Сухонос В.В. Організація і діяльність прокуратури в Україні: історія і сучасність. Суми : Університетська книга, 2004. С. 28-29.

27. Сухонос В.В. Прокуратура в механізмі української держави: проблеми теорії та практики : дис. ... д-ра юрид. наук : 12.00.10. Київ, 2009. C. 40. 
28. Сухонос В.В. Прокурорський нагляд за додержанням законів органами дізнання: історичний аспект. Прокуратура. Людина. Держава. 2004. № 9. C. 18-19.

29. Сухонос В.В. Прокуратура в системі державних органів України: теоретичний аналіз сучасного стану та перспектив розвитку : монографія. Суми : ВТД «Університетська книга», 2008. С. 68.

30. Шестопалов Р.М. Історичні передумови становлення та розвитку правозахисної діяльності органів прокуратури України. Науковий вісник Дніпропетровського державного університету внутрішніх справ. 2012. № 2. C. 145 .

31. Recommendation CM / Rec (2012) 11 of the Committee of Ministers to member States on the role of public prosecutors outside the criminal justice system. URL: https://www.coe.int/.

\section{Information about author:} Naulik N. S., Ph.D. in Law, Docent,

Head of the Department of Continuous Training of Civil Servants of the Public Prosecution Service Institute for Continuing Professional Development National Prosecution Academy of Ukraine 81-b, Yurii Illienko str., Kyiv, Ukraine 